\title{
Urban Farming Learning Application in Simulation Games for Generation $\mathrm{Z}$ in Indonesia
}

\author{
Sara Melati Sijabat ${ }^{1, *}$, Banung Grahita ${ }^{2}$ \\ ${ }^{1}$ Institut Teknologi Bandung, Indonesia \\ ${ }^{2}$ Institut Teknologi Bandung, Indonesia \\ *Corresponding author.Email: saramelatis@gmail.com
}

\begin{abstract}
This research aims to analyse the requirement needed in urban farming education and apply it to the mechanism in video games, especially in agriculture games. Urban farming is an activity of farming in urban areas as an effort to fulfil food needs and also maintain the sustainability of green open spaces. This activity is good for the residents of the city to know and do, especially with the increasing rate of urbanization and increasing food needs. One of the media that can teach about urban farming is through video games. Video games can make teaching and learning activities more effective and easier to accept, mainly for people who are learning about a new topic for the first time. With the repetitive nature of game mechanics, players can learn a method and strategy applied in a game, so the playing pattern can become familiar to the player. This research was conducted using a qualitative method, where a literature review was carried out on related theories, and a comparison of the mechanisms in several games that have farming gameplay using the MDA framework. The results of this study aim to determine the appropriate mechanism with the needed requirements to be applied to games as a medium for urban farming education so that generations can know how to start practicing urban farming. It is hoped that the results of this study can be useful for the basis of developing video games about urban farming or the like.
\end{abstract}

Keywords: Simulation game, urban farming, game mechanic, game design, generation

\section{INTRODUCTION}

In an article on news.detik.com, it is stated that the BPS population projection data shows that $66.6 \%$ of the population in Indonesia will live in urban areas by 2035 , and the World Bank estimates that $70 \%$ of Indonesia's population will live in urban areas in 2045 [1]. This is clearly able to cause many negative impacts on the environment, as an example if the population growth rate is greater than the rate of food production, then a food crisis can occur. This problem can be solved if we implement urban farming, especially in big cities where the main food source is usually from the food market. Urban farming is a gardening or farming activity in urban areas. With urban agriculture, urban citizens can supply some of their daily food needs efficiently, with fresh and organic ingredients, and can be tailored to the needs of each individual or family.
One of the age ranges that have a major impact on the growth of an individual is the adolescence age group, specifically middle adolescence, with an age range of 15-18 years. At the age of mid-teens, adolescents experience puberty where growth is almost complete, they have an awareness about the coming of adulthood, and the emergence of their new mindset changes [2]. With this change in mindset, the youth can be taught and introduced to new concepts that can have an impact on both their future and their lifestyle as adults.

One of the many ways to introduce urban farming can be done by using video games. This media can arouse the players' curiosity, stimulate their reactions, allow players to understand the object of the study, help them concretize something abstract and so on [3]. Games can give a structure that encourages or instils a behaviour in players that they can mimic and perform [4]. With the repetitive nature of game mechanics, players can learn a 
method and strategy applied in a game, so that this playing pattern can become familiar to players. The player discovers how the decisions they make impact the process's functionality through trial and error [5].

Simulation games are game genres that have the potential to increase learning motivation in players. Citing Garris et al., instructional content and characteristics of a game function as inputs in the game cycle (process), which ultimately affects learning outcomes [6]. And to achieve this, simulation games ideally use a combination of entertainment and active learning principles to attract players to study the material offered in simulation games.

One of the genres that can be explored as a reference for the application of urban farming learning is farming simulation games. This genre is well known and familiar among gamers. However, most of these farming simulation games no longer focus on traditional farming methods, but rather on running a business [7]. There are several aspects in learning urban farming, especially in the early steps of learning, which are not widely contained in these farming simulation games.

When about to start urban farming, especially in Indonesia, it is important to pay attention to starting points such as recognizing the planting area, paying attention to sunlight, paying attention to wind direction, water sources, making planting plans and recognizing types of vegetables. Some of these points do not always appear in most farming simulation games, so it is necessary to find mechanics of farming simulation games that are in accordance with the way of learning urban farming, especially for Generation $\mathrm{Z}$ in Indonesia.

\section{METHODOLOGY}

In this study, the author uses a qualitative method, analysing the interview and observation needed to find out the content needs for urban farming in Indonesia and the content needs for generation $\mathrm{Z}$. The data and findings are then applied in a comparison of the mechanisms of farming simulation games using the MDA framework, interpreted and a conclusion is drawn at the end in the form of gameplay recommendations which are in accordance with the needs of urban farming content for generation $\mathrm{Z}$. The games that are compared are Stardew Valley, Farm Together, and Plant Tycoon.

\section{CONTENT REQUIREMENT IDENTIFICATION}

\subsection{Indonesian Urban Farming Content Requirement}

Urban farming is applied to address the problem of increasing food demand in urban areas, which causes problems such as monoculture farming and the use of synthetic chemicals in mass farming, which can harm environmental ecosystems, according to a workshop held by WeGrow on March 142021 online about edible gardening. In addition, urban farming also has many benefits such as fulfilling some of the daily nutrition from home, serving fresh food, serving organic food, and the type of food can be adjusted according to needs.

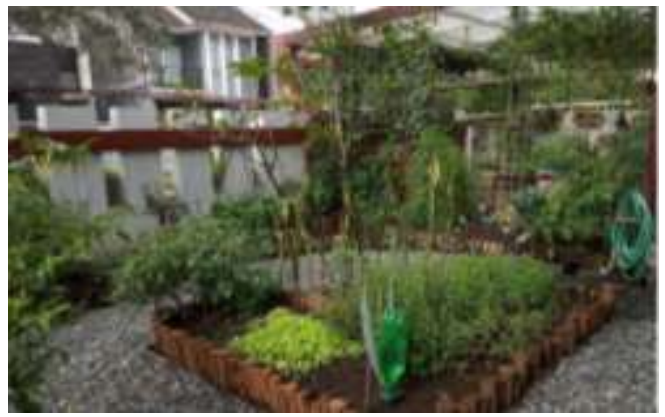

Figure 1 Example of Urban Farming Garden

The WeGrow workshop session also went over the steps to getting started in urban farming, including:

1. Identifying the planting area

The front or back yard, balcony, rooftop, outdoor staircase area, area under windows, fences, house walls, and many more areas in the residential area are all examples of land or vacant space that can be planted with plants. This may have an impact on the types of plants that are appropriate for growing in these places.

2. Sunlight

It's important to keep an eye on how the sun shines in the area. The angle in which the sun rises, the height of the wall that blocks the sun's beams, and the duration the sun is visible (full, partial, and indirect sunlight).

3. Wind direction

The direction of the wind is significant since it might cause plants with weak stems to topple. If the wind is particularly strong in the area, solutions such as planting windbreaks or erecting fences are required.

4. Water sources 
To avoid forgetting to water the plants on a regular basis, it is preferable if the water source is close to the planting area.

5. Make a planting plan

Planting plans are required to keep track of the many types of planting areas that are being worked on. To avoid the risk of mishandling the planting area and the plants themselves, give details on the type of planting area, such as dig plot, no dig plot, verticulture, planting in pots, and fence propagation.

6. Recognize the types of crops

It can be assessed what plants can and cannot be planted well after knowing the condition of the region that can be planted with plants.

\subsection{Generation Z Content Requirement}

The digital native generation, often known as Generation Z, is a group of people born after the year 2000. This generation was born, nurtured, and grew up surrounded by digital technology. Most of their activities, at school, at home, and in the community, are inextricably linked to digital media [8].

The dynamic and mobile generation $\mathrm{Z}$ is always connected to each other online, thanks to the internet. At the end of 2019, mobile users from generation $\mathrm{z}$ grew at a $25 \%$ faster rate than active users from the previous generation [8]. Generation $\mathrm{Z}$ also has a big role in the development of the game industry. With an average of 7.6 hours per month, Generation $\mathrm{Z}$ in Indonesia ranks third highest in the time spent playing games in a month globally [9].

In line with the variances in personality between generations and places, Generation $\mathrm{Z}$ gamers in Indonesia have their own distinct characteristics when compared to gamers in the Asia Pacific region. [10]. Despite their need to always be connected, Indonesian gamers do not really enjoy chatting in games. The majority of Indonesia's $\mathrm{Z}$ generation admits that they play games to pass the time in their leisure time, thus their playing style is more relaxed. Due to their always-connected nature, many gamers in Indonesia use social media not only to share their gaming experiences, but also to find out information about the games they play. Playing games is also a way for Generation $\mathrm{Z}$ to escape reality by creating a personal world in the game [10].

\section{FIGURES AND TABLES}

\subsection{Overview of Similar Simulation Games}

A farming simulation game is one that contains content that is similar to the experience of conducting urban farming. This category of video games enhances the experience of farming and selling crops, and they typically take place in rural regions. The farm simulation games examined are also popular among gamers. Here are three examples of farming simulation games that the writer feels have experience in farming that can be used in this research.

The first game is Stardew Valley. This game was developed by ConcernedApe and released in 2016. This game is a simulation RPG genre and can be played on many platforms, but was first released as a PC game. This game can be played as a single player or even as part of an online multiplayer session. Stardew Valley is a farming simulation game in which the player takes on the character of the grandson of a grandpa who inherits a plot of land and a little house in a small town called Pelican Town. Players can select the type of farm they desire, each with its own set of benefits and downsides. In order to reconstruct this destroyed farm, the player must work to enhance the farmland he inherited. In this game, players can buy seeds, arrange land for planting, sell and cook crops. Players can grow plants by digging the soil in the space provided, sowing seeds, watering and fertilizing, until the plants grow up to be harvested. There are many achievements that can be achieved in this game, thus making engagement with players even greater.

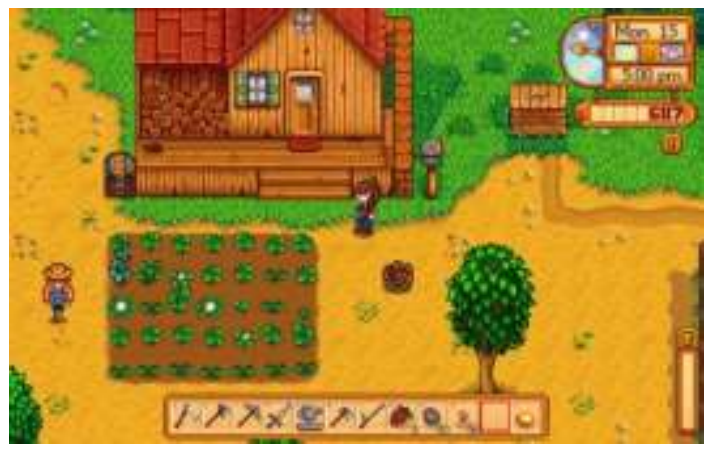

Figure 2 Stardew Valley game screen

The second game is titled Farm Together. This game was developed by Milkstone Studio and released in 2019. This game is a simulation genre with platforms on PC, Xbox One, PS4 and Switch, can be played in single player and multiplayer too, although it is recommended to play multiplayer in this game. This game provides a farm building experience that suits the player's preferences. In this 
game, players can also choose what kind of land specifications they will build a farm with all its plus and minus qualities. Players can expand their farms as they build experience and gain more money from selling crops, so that their farms get to expand. This is usually done by multiplayer players because the larger the farm, the harder it is to manage the entire farm. Plants that can be planted in this game have certain levels that can be unlocked by increasing experience in the game, and the higher the level, the greater the selling value of the plant. This game also applies real-time growth to the process of growing agricultural crops, so players have to wait in real time for their plants to grow.

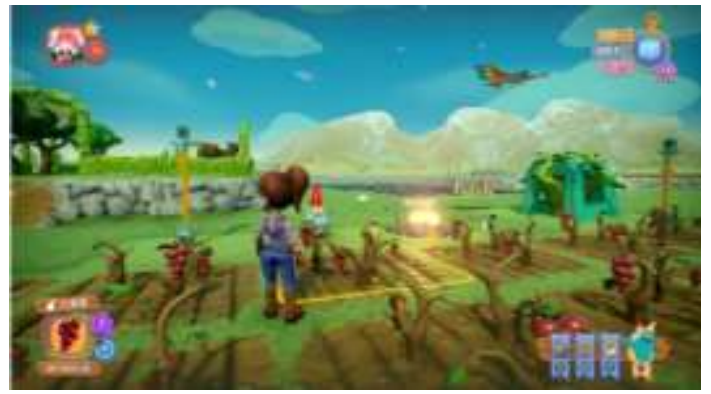

Figure 3 Farm Together! game screen

Work and is a farming gardening simulation genre. This game was released on the PC platform in 2007. Unlike other farming games, this game grows plants indoors. Players take on the role of the owner of a plant nursery who must cultivate many types of exotic plants, as well as keep his plant shop economically successful. This game has more mechanisms for caring for existing plants, with features such as researching soil, catching insect pests, and pruning your plants. The more players gain more experience from selling and cultivating crops, players will be able to upgrade their farming tools to more advanced ones using the in-game exchange rate.

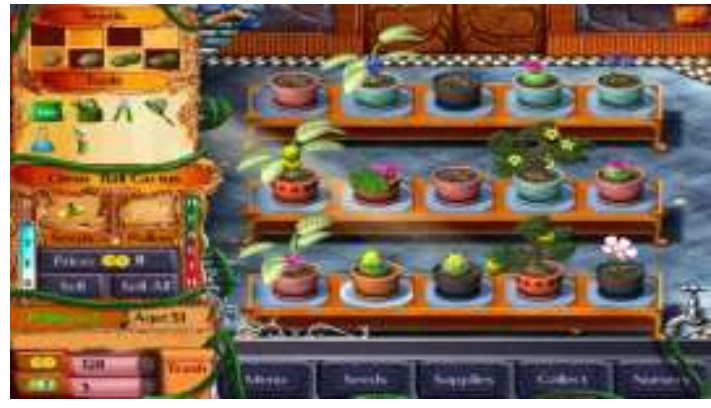

Figure 4 Plant Tycoon game screen

\subsection{Analysis of Similar Games Using the MDA Framework}

MDA is a formal approach to game understanding that aims to bridge the gap between game design and development, game critique, and technical game research [11]. This methodology is thought to clarify and reinforce the process of repeating the developers, scientists, and researchers, making it easier for all parties to elaborate, study and design a broad class of game design and game artifacts.

\subsubsection{Stardew Valley}

The aesthetic aspects of Stardew Valley include narrative, challenge, fellowship, discovery, and submitting. Stardew Valley creates a narrative about farm life in a small town with various experiences that occur as the game progresses. In addition to providing the experience of living in a rural area, Stardew Valley also provides players with a new experience where players can feel the routine in a small peaceful town. Stardew Valley has a laid-back vibe to it, letting the player take things easy.

To carry out those components in Aesthetics, the Stardew Valley developer uses quests to keep the player engaged and carried the narrative well, as well as enjoying all of the aesthetics available in this farming game. Narration is carried across the game's events and missions, allowing the player to move through the tale as well as the farm growth. Fellowship arises from the game's multiplayer feature, which allows players to interact socially while maintaining the farm

The mechanics used in order to carry the dynamic in this game are various. The main resource in this game is money. In order to make money, players have to sell the plants they grow, and with the money they can buy new seeds to grow more plants. There's also drains and maintenance in the game regarding growing the farm crops. There's a weather system, which brings some advantages and disadvantages for the player. For example, if it's raining, the player doesn't have to water the crops anymore, and if you don't place a scarecrow there might be a chance for your crop to be eaten by birds.

\subsubsection{Farm Together!}

Farm Together has a fellowship aesthetic, as well as discovery, challenge, and submission. The game offers multiplayer so the player can manage the farm with other players. It also offers a new experience on farming, and keeps the player engaged with unlockable crop varieties. The challenge in the game is to expand the farm, feature and/or area, as the 
player gains experience from tending and selling the crops. The game can also be played in the player's pastime as there's no time consequences in the game.

The main dynamic here is to grow your crops with real time flow, so if the crop needs ten minutes to fully grow, then the player has to wait ten minutes real time to harvest the crop. With this dynamic, the fellowship aesthetic is shown as the multiplayer gamers take turns to tend the crop and manage the farm. The player is kept engaged with various achievable achievement bonuses as they gain experiences from managing the farm.

Farm together also has a resource mechanic, as the player has to manage several in-game currency to buy more items for their farm, be it crops, accessories, new buildings, etc. The game also has a construction converter mechanic where the player can build buildings from the resource in the game.

\subsubsection{Plant Tycoon}

Plant Tycoon has the fantasy, challenge, discovery and submission aesthetic. The game offers a fantasy universe where there's various fantasy plants to be taken care of. There's also a challenge, which the player has to manage to breed the legendary seeds from breeding the plants until they come up with it. There's no time limit, so the game is able to be played as a pastime activity.

The dynamic to carry the aesthetic in Plant Tycoon is also various. The game provides several achievements so the player stays engaged in-game and carries on with the challenges. The player can also discover more technical experience in caring for plants or crops indoors, with all the tools and requirements needed to tend the plants so they grow healthy.

Plant Tycoon has a more detailed crop maintenance mechanic, as the player should prune, spray, catch bugs, and fertilize the plants to keep them healthy as a resource to gain more in-game currency. Players can and should sell their plants to gain more money in order to buy more plants to care for and breed. The game's level can be shown with how many plants the player has unlocked.

\subsection{Conclusion}

Seen from the description of the game analysis above, most of these farming simulation games have aesthetic challenges, discovery, and submissions in the game, and have different dynamics to convey aesthetics in the game. The mechanisms used also vary, but the core mechanics used mostly use resource management to be able to progress in terms of experience.

In relation to the needs of urban farming content and content for Generation $\mathrm{Z}$ in Indonesia, some adjustments are needed to meet these needs in the simulation game that will be designed. Aesthetic game content can still be related to the aesthetics shown in the previous example of farming simulation games, but there needs to be dynamic adjustments and mechanisms that must be adapted to the needs of urban farming simulation games in Indonesia for generation $\mathrm{Z}$.

\section{REFERENCES}

[1] Urbanisasi Melaju Cepat, Kita Bisa Apa? [Internet]. [Cited 2021 July 20]. Available from https://news.detik.com/kolom/d5233999/urbanisasi-melaju-cepat-kita-bisa-apa

[2] R. Aryani, Kesehatan Remaja Problem dan Solusinya, Penerbit Salemba Medika, Jakarta, 2010.

[3] JMGP. Pramono, C. Ranuntu, L. Kalangi, Pengaruh Media Game Komputer Terhadap Pembelajaran Kosakata Bahasa Inggris Pada Anak. Kajian Linguistik, VI(2), 2019, pp. 5567.

[4] R. Glas, VJ. Van VJ, Considering play, 2004.

[5] E. Adams, Fundamentals of Construction and Simulation Game Design, New Riders, 50; 2013.

[6] TA. Sitzmann, Meta-Analytic Examination Of The Instructional Effectiveness Of ComputerBased Simulation Games, Personnel Psychology, 2011, 64(2), pp. 489-528.

[7] Koster RA. Theory of Fun for Game Design 2nd Edition. 2013.

[8] Z. Hidayat Z, A. Saefuddin, S. Sumartono, Motivasi, Kebiasaan, dan Keamanan Penggunaan Internet, In: Jurnal ILMU KOMUNIKASI, 13(2), 2017, pp. 129.

[9] Understanding the mobile habits of Indonesia's Gen Z: WARC, WARC An Ascential Company - WARC [internet]. [cited 2021 July 23]. Available from https://www.warc.com/newsandopinion/news/u nderstanding-the-mobile-habits-of-indonesiasgen-z/43040 
[10] Survei Twitter: Gamer Indonesia Punya Karakteristik Unik: Hybrid. Esports, review, gaming gear [internet]. [cited 2021 July 23]. Available from https://hybrid.co.id/post/trengame-indonesia-twitter

[11] R. Hunicke, M. Leblanc, R. Zubek, MDA: A formal approach to game design and game research, AAAI Workshop - Technical Report, WS-04-04, 2004, pp. 1-5. 